\title{
ЭКОНОМИКА
}

ECONOMY

УДК 339.564:620.91(5:265)

DOI dx.doi.org/10.24866/1813-3274/2020-1/15-29

И. В. Филимонова ${ }^{1}$, ИНГГ СО РАН, г. Новосибирск, Россия

E-mail: FilimonovaIV@list.ru

В. Ю. Немов ${ }^{2}$, ИНГГ СО РАН, г. Новосибирск, Россия

E-mail: Void-pilgrim@mail.ru

И. В. Проворная ${ }^{3}$, ИНГГ СО РАН, г. Новосибирск, Россия

E-mail: ProvornayaIV@gmail.com

А. В. Чеботарева ${ }^{4}$, ИНГГ СО РАН, г. Новосибирск, Россия

E-mail: anstasiya0310@gmail.com

\section{ВОСТОЧНЫЙ ВЕКТОР СОТРУДНИЧЕСТВА РОССИИ СО СТРАНАМИ АЗИАТСКО-ТИХООКЕАНСКОГО РЕГИОНА В ЭНЕРГЕТИЧЕСКОЙ СФЕРЕ}

\footnotetext{
${ }^{1}$ Ирина Викторовна Филимонова, доктор экономических наук, профессор, заведующая Центром экономики недропользования нефти и газа Института нефтегазовой геологии и геофизики им. А. А. Трофимука СО РАН, заведующая кафедрой политической экономии экономического факультета Новосибирского государственного университета, г. Новосибирск, Россия.

${ }^{2}$ Василий Юрьевич Немов, кандидат экономических наук, старший научный сотрудник Центра экономики недропользования нефти и газа Института нефтегазовой геологии и геофизики им. А. А. Трофимука СО РАН, доцент кафедры политической экономии экономического факультета Новосибирского государственного университета, г. Новосибирск, Россия.

${ }^{3}$ Ирина Викторовна Проворная, кандидат экономических наук, доцент, старший научный сотрудник Центра экономики недропользования нефти и газа Института нефтегазовой геологии и геофизики им. А. А. Трофимука СО РАН, доцент кафедры политической экономии экономического факультета Новосибирского государственного университета, г. Новосибирск, Россия.

${ }^{4}$ Анастасия Владимировна Чеботарева, младший научный сотрудник Центра экономики недропользования нефти и газа Института нефтегазовой геологии и геофизики им. А. А. Трофимука СО РАН, г. Новосибирск, Россия.

Для циитирования: Филимонова И. В., Немов В. Ю., Проворная И. В., Чеботарева А. В. Восточный вектор сотрудничества России со странами Азиатско-Тихоокеанского региона в энергетической сфеpe // Азиатско-Тихоокеанский регион: экономика, политика, право. 2020. № 1. С. 15-29.

Исследование выполнено при поддержке гранта Президента РФ МК-1459.2019.6 и гранта РФФИ в рамках научного проекта № 18-310-20010.
}

(С) Филимонова И. В., Немов В. Ю., Проворная И. В., Чеботарева А. В., 2020 
Аннотация. В статье проанализирована роль Азиатско-Тихоокеанского региона в экспорте нефти и газа из России. Оценен экспортный потенциал восточных регионов России. Уделено внимание транспортной инфраструктуре экспортного назначения, охарактеризован трубопроводный транспорт на востоке России, проанализирована доля объёма транспортировки углеводородов в совокупном производстве энергоносителей в России. Изучена динамика изменения стоимостной структуры экспортируемых энергоносителей из России. Авторами исследована также структура потребления и производства энергоносителей в странах АTP, Ceверной Америки и Европы. Отдельно рассмотрены мировые рынки нефти и газа, а также перспективы сотрудничества со странами АТР в энергетической сфере.

Ключевые слова: энергетическое сотрудничество, трубопровод, транспортировка нефти на экспорт, Азиатско-Тихоокеанский регион, топливно-энергетический баланс, потребление энергоносителей, производство нефти и газа, Восточная Сибирь, Дальний Восток. 


\title{
Irina V. Filimonova ${ }^{1}$
}

IPGG SB RAS, Novosibirsk, Russia

E-mail: FilimonovaIV@list.ru

\author{
Vasiliy Yu. Nemov ${ }^{2}$ \\ IPGG SB RAS, Novosibirsk, Russia \\ E-mail: Void-pilgrim@mail.ru
}

Irina V. Provornaya ${ }^{3}$

IPGG SB RAS, Novosibirsk, Russia

E-mail: ProvornayaIV@gmail.com

\author{
Anastasia V. Chebotareva ${ }^{4}$ \\ IPGG SB RAS, Novosibirsk, Russia \\ E-mail: anstasiya0310@gmail.com
}

\section{EASTERN VECTOR OF COOPERATION BETWEEN RUSSIA AND COUNTRIES OF THE ASIA-PACIFIC REGION IN THE ENERGY SECTOR"}

Abstract. The article analyzes the role of the Asia-Pacific region in the export of oil and gas from Russia. The export potential of the eastern regions of Russia was evaluated, attention was also paid to transport infrastructure for export, pipeline transport in the east of Russia was characterized, the share of hydrocarbon transportation in the total energy production in Russia was analyzed. The dynamics of changes in the cost structure of ex-

\footnotetext{
${ }^{1}$ Irina V. Filimonova, Doctor of Economics, Professor, Head of the Center for Economics of Subsoil Use of Oil and Gas, Institute of Petroleum Geology and Geophysics, named after A. A. Trofimuk, SB RAS, Head of the Department of Political Economy, Faculty of Economics, Novosibirsk State University, Novosibirsk, Russia.

${ }^{2}$ Vasily Yu. Nemov, Ph.D. (econ.), senior researcher at the Center for Economics of Subsoil Use of Oil and Gas, Institute of Petroleum Geology and Geophysics, named after A. A. Trofimuk, SB RAS, Head of the Department of Political Economy, Faculty of Economics, Novosibirsk State University, Novosibirsk, Russia.

${ }^{3}$ Irina V. Provornaya, $\mathrm{PhD}$ in Economics, Associate professor, senior researcher, Center for Economics of Subsoil Use of Oil and Gas, Institute of Petroleum Geology and Geophysics, named after A. A. Trofimuk, SB RAS, Head of the Department of Political Economy, Faculty of Economics, Novosibirsk State University, Novosibirsk, Russia.

${ }^{4}$ Anastasia V. Chebotareva, junior researcher, Center for Economics of Subsoil Use of Oil and Gas, Institute of Petroleum Geology and Geophysics, named after A. A. Trofimuk, SB RAS, Head of the Department of Political Economy, Faculty of Economics, Novosibirsk State University, Novosibirsk, Russia.

For citing: Filimonova I. V., Nemov V. Yu., Provornaya I. V., Chebotareva A. V. Eastern vector of cooperation between Russia and countries of the Asia-Pacific region in the energy sector // PACIFIC RIM: Economics, Politics, Law. 2020. No 1. P. 15-29.

* The study was supported by a grant from the President of the Russian Federation MK-1459.2019.6 and a grant from the Russian Federal Property Fund in the framework of scientific project No. 18-310-20010.
} 
ported energy from Russia was studied. The authors also investigated the structure of energy consumption and production in the Asia-Pacific countries, North America and Europe. The world oil and gas markets, as well as the prospects for cooperation with the Asia-Pacific countries in the energy sector were separately considered.

Key words: energy cooperation, pipeline, oil transportation for export, Asia-Pacific region, fuel and energy balance, energy consumption, production of oil and gas, East $\mathrm{Si}$ beria, the Far East.

\section{Введение}

В соответствии с Доктриной энергетической безопасности РФ, утверждённой Указом Президента РФ от 13 мая 2019 г. № 216, одним из главных внешнеэкономических вызовов для энергетической безопасности страны и отечественного нефтегазового комплекса названо перемещение центра мирового экономического роста в Азиатско-Тихоокеанский регион (АТР).

В последние годы происходит расширение торговых и экономических связей России со странами АТР, прежде всего обусловленное изменением отношений с европейскими и североамериканскими странами вследствие введения ими в 2014 г. финансовых и секторальных санкций. Однако предпосылки расширения кооперации с Азиатско-Тихоокеанским регионом сложились значительно раньше [4, 4]. Долгие годы основной позицией в товарообороте выступали металлы, но с момента запуска в 2008 г. магистрального нефтепровода «Восточная Сибирь - Тихий океан» и строительства спецморнефтепорта Козьмино таковой стало нефтяное сырьё. Новую эру сотрудничества в конце 2019 г. открыло начало поставок природного газа по газопроводу «Сила Сибири».

Рост сотрудничества в энергетической сфере обусловливает необходимость комплексного исследования динамики развития Азиатско-Тихоокеанского рынка углеводородов и изменения его роли в структуре мирового топливно-энергетического баланса. Рост поставок сырья на азиатские рынки позволит решить не менее важную стратегическую задачу, обозначенную в Доктрине энергетической безопасности РФ, - диверсификацию поставок и противодействие дискриминации российских организаций, экспортирующих нефть и продукты её переработки на европейском рынке.

\section{Роль АТР в экспорте из России}

Россия располагает самым крупным в мире энергетическим потенциалом. Доля экспорта в общем объёме добычи нефти в России составляет 47 \%, экспорт произведенных нефтепродуктов составляет 50 \%, благодаря поэтапному вводу в эксплуатацию завода «Ямал СПГ» доля экспортируемого газа выросла с 34 \% в 2018 г. до $37 \%$ в 2019 г. (рис. 1). 


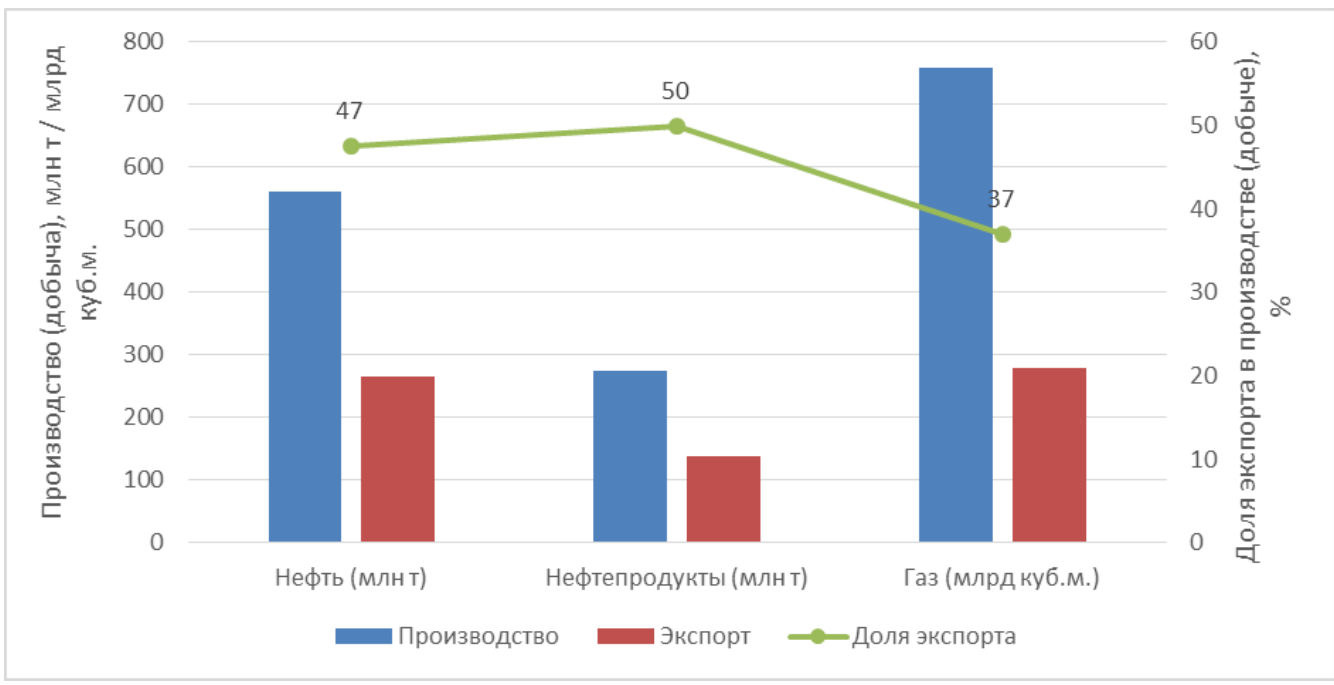

Puc. 1. Доля экспорта в производстве (добыче) энергоносителей в России в 2019 г. Источник: рассчитано авторами

Несмотря на влияние экономических кризисов и мер по диверсификации экономики России, сохраняется высокая зависимость от экспорта энергетических ресурсов $[1,7]$. В стоимостной структуре экспорта товаров из России на нефтегазовые ресурсы (нефть, нефтепродукты, газ) приходится 58 \%. Поступления от экспортной пошлины долгие годы составляли 30 \% доходов федерального бюджета. С началом «налогового манёвра» в 2015 г. и одновременном ухудшении ценовой конъюнктуры на мировых энергетических рынках доля поступлений от экспорта нефти и газа в бюджет сократилась до $20 \%$ (рис. 2).

В дальневосточных регионах России сосредоточена значительная часть энергетических ресурсов, а страны АТР представляют крупнейший мировой центр потребления нефти, нефтепродуктов, а также самый динамично развивающийся рынок природного и сжиженного газа. В последнее десятилетие в России высокими темпами идёт развитие транспортной инфраструктуры на востоке страны, способствующей росту поставок энергетических товаров на рынок стран АТР [6]. Так, закончено формирование магистральной нефтепроводной системы «Восточная Сибирь - Тихий океан», развивается газопроводная инфраструктура (2 декабря 2019 г. начаты поставки по газопроводу «Сила Сибири»), расширяются мощности по перевалке грузов в портах, реализуются новые проекты СПГ [2]. В настоящее время на рынок АТР приходится 34 \% экспорта нефти, 15 \% экспорта нефтепродуктов и 6 \% экспорта газа (рис. 3). Крупнейшие торговые партнёры на этом рынке - Китай, Япония и Корея.

Долгие года факторами, сдерживающими сотрудничество России со странами АТР, были неразвитость транспортной инфраструктуры, низкая степень геологиче- 
ской изученности территории Восточной Сибири и Дальнего Востока, а также отсутствие государственных механизмов стимулирования и повышения эффективности деятельности хозяйствующих субъектов в удалённых регионах азиатской части страны. Вместе с тем, начало кооперации в энергетической сфере стимулировало развитие дальневосточных регионов страны, присутствие крупного бизнеса нефтегазового и финансового секторов экономики способствует решению социальноэкономических и внешнеэкономических задач.

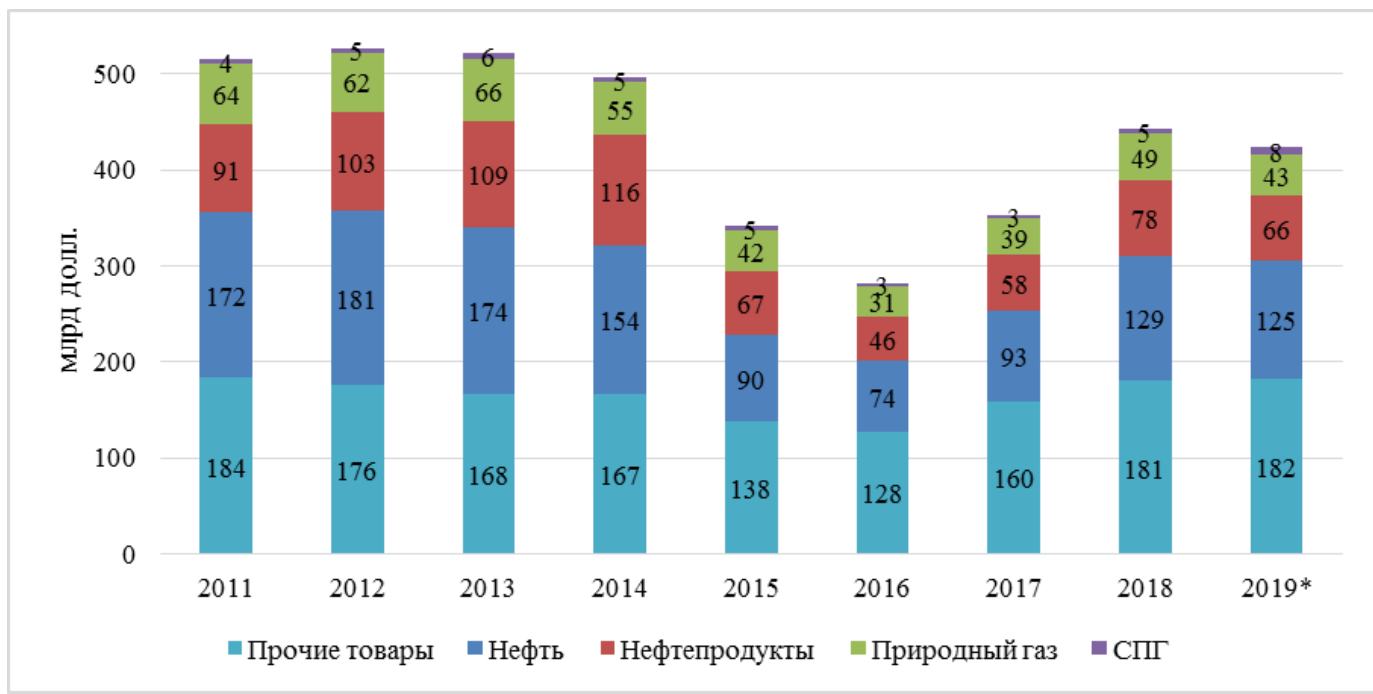

Рис. 2. Динамика стоимостной структуры экспорта товаров из России, млрд долл.

(в 2019 г. - оценка по трём кварталам)

Источник: рассчитано авторами

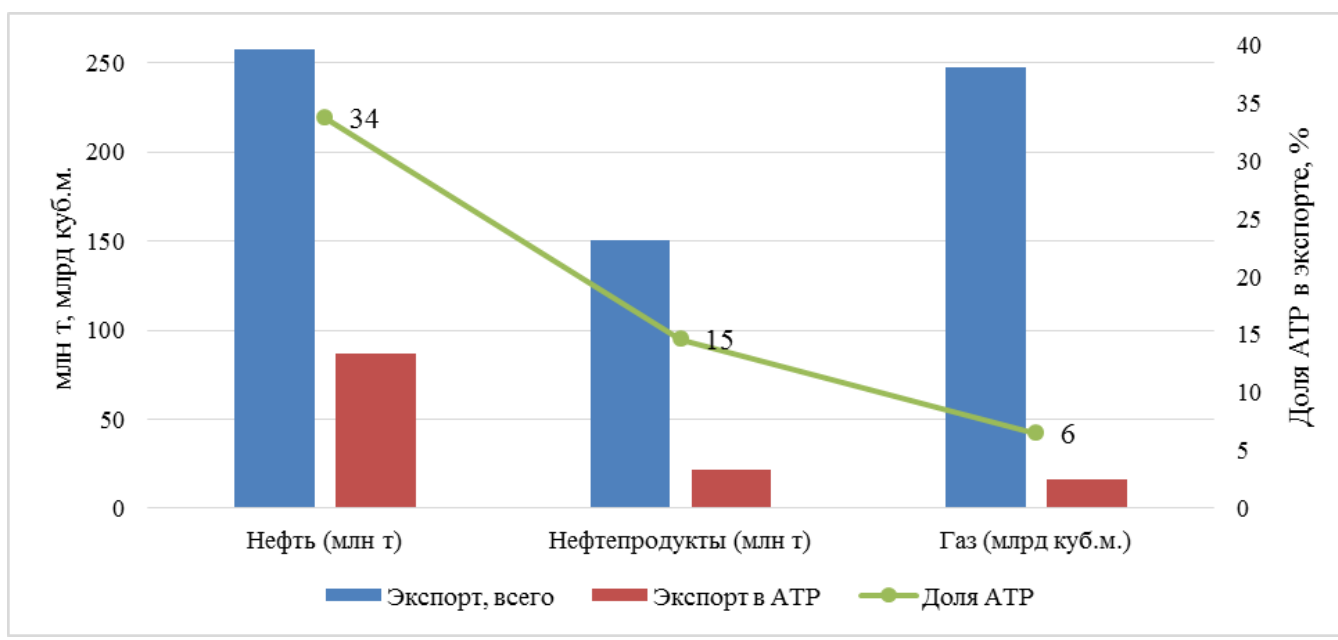

Рис. 3. Роль АТР в экспорте энергоносителей из России в 2018 г.

Источник: рассчитано авторами 
Филимонова И. В., Немов В. Ю., Проворная И. В., Чеботарева А. В. Восточный вектор сотрудничества России со странами Азиатско-Тихоокеанского региона в энергетической сфере

\section{Экспортный потенциал восточных регионов России}

В 2019 г. продолжился рост объёма транспортировки нефти на экспорт по магистральному нефтепроводу ВСТО вследствие увеличения мощности отдельных участков трубопроводной системы - ВСТО-1 и ВСТО-2. По итогам 2019 г. объём экспортных поставок нефти по ВСТО составил 63,2 млн т. Относительно 2016-2017 гг. экспортные поставки выросли на 31 \% (табл. 1). Основную часть мощности трубопровода заполняет нефть из месторождений Восточной Сибири и Республики Саха (Якутия). В последние годы добыча в регионе держится на уровне 55 млн т. Несмотря на то, что месторождения Ванкоро-Сузунской зоны в геологическом плане относятся к Западносибирской нефтегазоносной провинции, по административному делению они расположены в Красноярском крае, поэтому их целесообразно рассматривать в составе восточносибирского региона.

Таблица 1

\section{Экспорт нефти из Восточной Сибири и Дальнего Востока}

\begin{tabular}{|l|r|r|r|r|r|c|}
\hline $\begin{array}{c}\text { Источник поставки / } \\
\text { направление экспорта }\end{array}$ & 2012 & 2014 & 2016 & 2018 & 2019 & $2019 / 2018$ гг., \\
\hline ВСТО*, всего & $\mathbf{3 1 , 4}$ & $\mathbf{4 1}$ & $\mathbf{4 8 , 3}$ & $\mathbf{5 9 , 6}$ & $\mathbf{6 3 , 2}$ & $\mathbf{1 0 6 , 0}$ \\
\hline Порт Козьмино & $\mathbf{1 6 , 3}$ & $\mathbf{2 4 , 9}$ & $\mathbf{3 1 , 8}$ & $\mathbf{3 1 , 3}$ & $\mathbf{3 3 , 2}$ & $\mathbf{1 0 6 , 1}$ \\
\hline Китай & 4,1 & 7,4 & 22,2 & 25,5 & 25,9 & 101,6 \\
\hline Япония & 4,9 & 8,5 & 3,9 & 3,3 & 2,3 & 70,4 \\
\hline Южная Корея & 1 & 3 & 2,4 & 0,8 & 2,0 & 249,0 \\
\hline Прочие & 6,4 & 6 & 3,3 & 1,8 & 3,0 & 166,0 \\
\hline $\begin{array}{l}\text { Нефтепровод-отвод } \\
\text { «Сковородино- Дацин» }\end{array}$ & $\mathbf{1 5 , 1}$ & $\mathbf{1 6 , 1}$ & $\mathbf{1 6 , 5}$ & $\mathbf{2 8 , 3}$ & $\mathbf{3 0}$ & $\mathbf{1 0 6 , 0}$ \\
\hline Китай & 15,1 & 16,1 & 16,5 & 28,3 & 30 & 106,0 \\
\hline Минуя систему ВСТО & $\mathbf{1 2 , 6}$ & $\mathbf{1 3 , 3}$ & $\mathbf{1 6 , 8}$ & $\mathbf{1 7 , 2}$ & $\mathbf{1 7 , 9}$ & $\mathbf{1 0 4 , 2}$ \\
\hline Де-Кастри & 7,1 & 7,9 & 11,3 & 11,6 & 13,0 & 111,8 \\
\hline Пригородное & 5,5 & 5,4 & 5,5 & 5,6 & 4,9 & 88,3 \\
\hline
\end{tabular}

* Часть нефти поступает из Западной Сибири; без учёта поставок на Комсомольский НПЗ

Источник: рассчитано авторами

В период 2015-2017 гг. наблюдались задержки со строительством трубопроводной инфраструктуры на территории Китая и в подготовке технических условий к приёму российской нефти на китайских НПЗ. Однако уже в 2018 г. были завершены работы по вводу в эксплуатацию китайского участка нефтепровода «Сковородино - Дацин», а в 2019 г. объём прокачки вышел на проектный уровень - 30 млн т нефти в год.

Крайней точкой нефтепроводной системы ВСТО II является спецморнефтепорт Козьмино, объём экспорта через который в 2019 г. составил 33,2 млн т, что на 
$6,1 \%$ больше, чем в предыдущем году. В настоящее время мощности порта по перевалке нефти полностью загружены.

Страны Азиатско-Тихоокеанского региона - основное направление транспортировки нефти из Восточной Сибири и Республики Саха (Якутия). Значительная часть поставок, до 78 \% в 2019 г., осуществляется в Китай. Выгодное расположение порта позволяет отгружать нефтяное сырьё и в другие страны АТР, например, Японию (7 \%) и Южную Корею (6 \%). Меньшие объёмы поставок приходятся на Новую Зеландию, Малайзию, Сингапур, Филиппины, Таиланд и США. В последние годы рост поставок нефти в США позволил России занять второе место среди поставщиков нефти в эту страну.

Помимо восточного направления экспорт углеводородов и продуктов их переработки в Азиатско-Тихоокеанский регион также осуществляется из портов в европейской части России.

Рынок Азиатско-Тихоокеанского региона является важным направлением российской экспортной газовой политики. До декабря 2019 г. поставки природного газа осуществлялись только в форме СПГ с завода по сжижению газа в рамках проекта «Сахалин-2», акционерами разработки которого являются ОАО «Газпром», Shell, Mitsui и «Мицуи» Mitsubishi. Основным экспортным направлением транспортировки СПГ являются страны АТР - Китай, Тайвань, Южная Корея и Япония.

В 2019 г. в региональной структуре Япония продолжила занимать лидирующее положение среди стран АТР. По итогам года объём экспорта СПГ в Японию из России сократился на 1,6 млн т и составил 6,2 млн т (рис. 4).

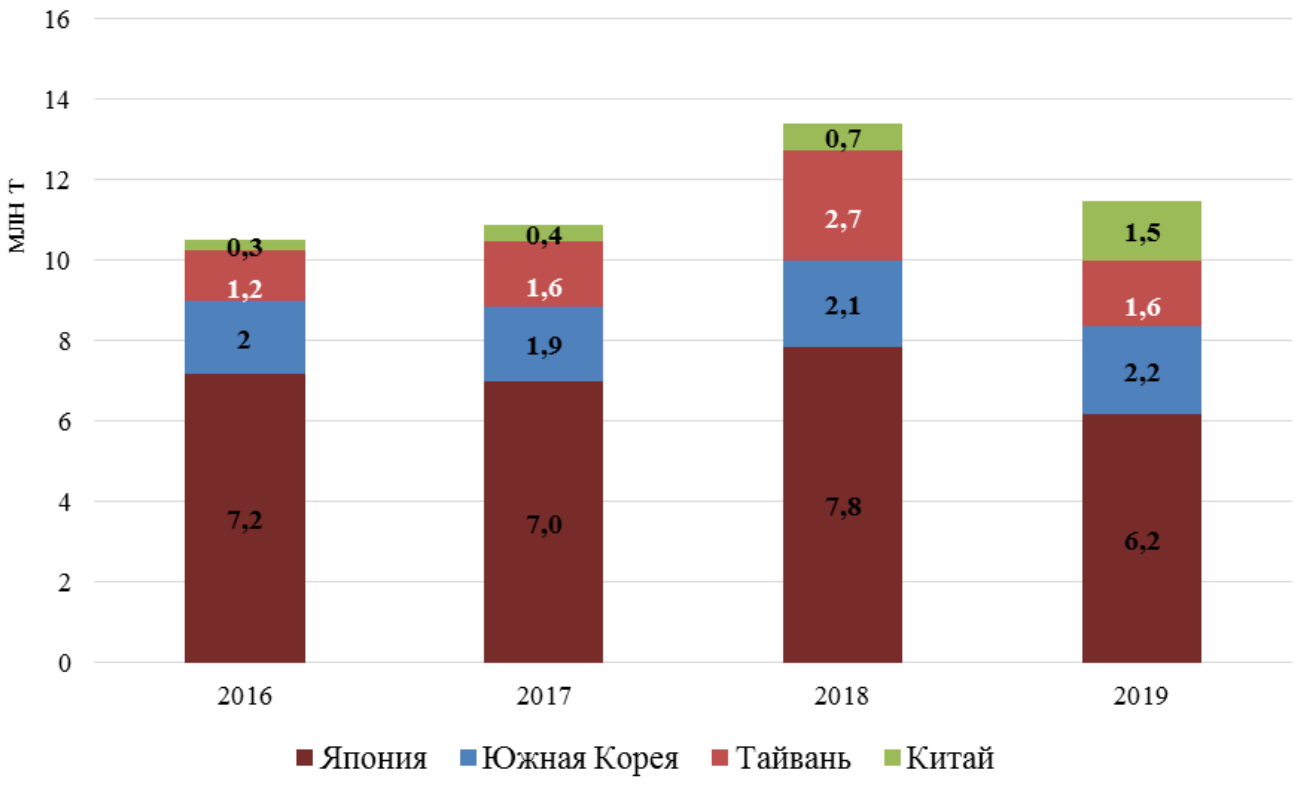

Puc. 4. Экспорт сжиженного природного газа из России в страны АТР Источник: рассчитано авторами 
Филимонова И. В., Немов В. Ю., Проворная И. В., Чеботарева А. В. Восточный вектор сотрудничества России со странами Азиатско-Тихоокеанского региона в энергетической сфере

Вторым важным направлением поставок сжиженного газа на экспорт является Южная Корея, в 2019 г. объём транспортировки увеличился на 0,1 млрд куб. м по сравнению с 2018 г. (2,2 млн т). Экспорт в Тайвань в 2019 г. уменьшился на 1,1 млн т и составил 1,6 млн т. Однако наблюдалось увеличение экспорта СПГ в Китай с 0,7 млн т до 1,5 млн т, преимущественно за счёт развития проекта ЯмалСПГ, но основу пока составляет проект «Сахалин-2».

\section{Транспортная инфраструктура экспортного назначения}

Восточное направление экспортных поставок нефти получило развитие с началом эксплуатации трубопроводной системы «Восточная Сибирь - Тихий океан» (ВСТО). Строительство магистральной инфраструктуры на востоке страны и отводящих нефтепроводов стимулировало освоение ресурсного потенциала регионов Восточной Сибири и Республики Саха (Якутия). Нефтепровод ВСТО объединил единой транспортной системой нефтяные месторождения Западной и Восточной Сибири с портовой инфраструктурой на Дальнем Востоке. Такая интеграция открыла новые возможности сотрудничества со странами Азиатско-Тихоокеанского региона в энергетической сфере.

Магистральный трубопровод ВСТО спроектирован из двух крупных участков. Во-первых, это участок ВСТО I по направлению «Тайшет - Сковородино» с дальнейшим продолжением на Китай в направлении «Сковородино - Мохэ». Во-вторых, участок ВСТО ІІ по направлению «Сковородино - Козьмино» и с выходом на тихоокеанское побережье. Общая протяжённость нефтепровода составляет 4740 км. В конце 2019 г. «Транснефть» завершила реализацию проекта «ВСТО», что позволило вывести нефтепровод на максимальную проектную мощность. Максимальный объём перекачки нефти на участке ВСТО-1 составляет 80 млн т нефти в год, на участке ВСТО-2 - 50 млн т нефти. В конце 2019 г. начались также поставки нефти по нефтепроводу-отводу на Комсомольский НПЗ. В результате общий объём прокачки нефти по ВСТО вырос в 2019 г. на $11 \%$.

Увеличение мощности нефтепровода ВСТО позволят наращивать объём экспорта через порт Козьмино. Так в 2020 г. ожидаемый объём отгрузки нефти составляет 34 млн т. Увеличение ёмкости резервуарного парка и дноуглубительные работы должны позволить увеличить мощность порта до 36 млн т нефти в год.

Основой для роста экспортного потенциала природного газа на рынок стран АТР является развитие проектов «Сила Сибири» и «Сила Сибири-2», а также строительство новых мощностей по производству СПГ.

В конце 2019 г. состоялся запуск магистрального газопровода «Сила Сибири». Газопровод спроектирован преимущественно вдоль трассы нефтепровода ВСТО, что, с одной стороны, в определённой степени удешевило строительство, а, с другой стороны, позволит в будущем организовать сбор природного газа с место- 
рождений, которые наряду с нефтью содержат и природный газ. Трасса газопровода проходит по территории пяти субъектов РФ - Республики Саха (Якутия), Иркутской и Амурской областей, Еврейской автономной области и Хабаровского края. Маршрут трассы «Силы Сибири» проложен вдоль действующего магистрального нефтепровода «Восточная Сибирь - Тихий океан». Максимальная прокачка газа по трубе может составить 38 млрд куб. м газа в год. Источником первых поставок газа является Чаяндинское месторождение в Республике Саха (Якутия), в 2020 г. объём транспортировки газа достигнет 4-5 млрд куб. м. В конце 2022 г. планируется начало подачи газа в газопровод с Ковыктинского месторождения в Иркутской области. Для извлечения гелия и других ценных компонент из газа уникальных месторождений ведётся строительство Амурского ГПЗ. Однако ввод в эксплуатацию первых двух очередей завода планируется в конце 2021 г., а выход на полную мощность ожидается к 2025 г.

На стадии разработки находится проект газопровода «Сила Сибири-2» для транспортировки газа с месторождений Западной Сибири в Китай через территорию Монголии.

\section{Энергетические рынки стран Азиатско-Тихоокеанского региона}

На протяжении последних 40 лет центр роста потребления энергетических ресурсов приходится на страны АТР с быстро растущей экономикой. В период с 1980 г. по 2018 г. доля этого региона в структуре энергопотребления выросла с 17,6 \% до 43,2 \%. При этом среднегодовой темп прироста потребления энергоносителей в странах АТР составил 4,4 \%. По итогам 2018 г. потребление энергоносителей выросло на 4,1 \%, или на 237,8 млн т н. э. Крупнейшие потребители энергетических ресурсов в регионе - Китай (23,6 \% мирового энергопотребления), Индия $(5,8 \%)$, Япония $(3,3 \%)$ и Южная Корея $(2,2 \%)$.

Одним из ключевых факторов роста энергопотребления в АТР является увеличение численности населения, а также рост числа транспортных средств. Поэтому в регионе прогнозируется увеличение потребления всех без исключения энергоносителей для удовлетворения растущих потребностей населения и развитии промышленного потенциала.

\section{Структура потребления энергоносителей}

АТР - крупнейший регион по уровню энергопотребления, определяющий основные тенденции в изменении структуры энергопотребления. В АзиатскоТихоокеанском регионе потребляется более 41 \% мировых энергетических ресурсов $[8$, с. 9$]$.

В структуре энергопотребления в АТР доминирует уголь, доля которого составляет 48 \%. Высокая доля угля обусловлена тем, что в период бурного роста 
экономики Китая с начала 2000-х гг. всё возрастающий спрос на энергию обеспечивался преимущественно за счёт внутренних ресурсов - добычи угля. Однако в последнее десятилетие Китай высокими темпами развивает газотранспортную инфраструктуру для обеспечения импортных поставок и развивает собственную добычу природного газа, при этом с 2014 г. сокращается добыча угля. В то же время спрос на уголь поддерживается со стороны Индии и Индонезии: за период 2010-2018 гг. потребление угля в этих странах выросло на 56 \%.

Второй по объёму потребления энергоноситель - нефть, спрос на которую характеризуется стабильным ростом. С 2010 г. потребление нефти в АТР выросло на 26 \%, а среднегодовой темп прироста составил $3,4 \%$. Основными потребителями нефти в регионе являются Китай (38 \%), Индия (14 \%) и Япония (11 \%). При этом в Японии с 2012 г. потребление нефти стабильно сокращается средним темпом 3,4 \% в год (рис. 5).

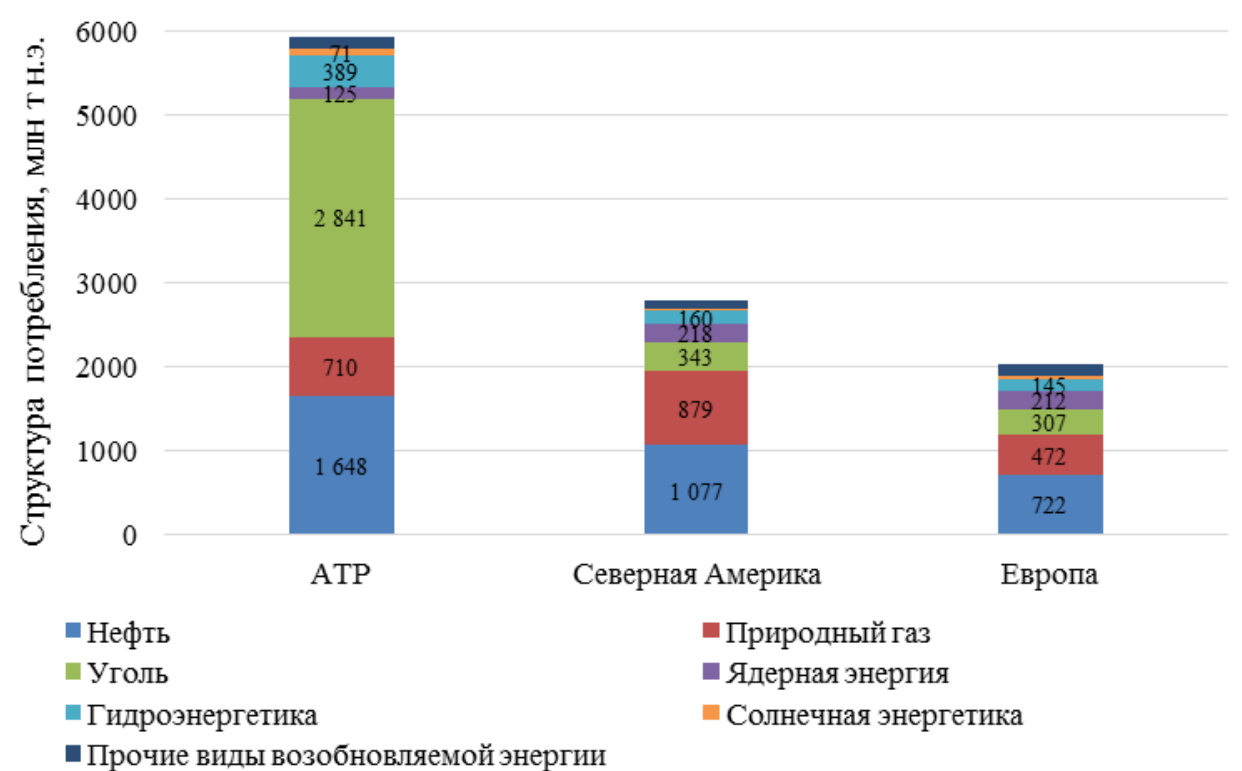

Puc. 5. Структура потребления энергетических ресурсов Источник: рассчитано авторами

На природный газ приходится 11,9 \% энергопотребления. С 2010 г. потребление выросло на $43 \%$, а среднегодовой темп прироста составил 5,2 \%. Быстрее всего спрос растёт в Китае, где за период 2010-2018 гг. потребление выросло в 2,6 раза. Также высоким темпом потребление газа растет в Австралии, Японии, Южной Корее.

На развитие ядерной энергетики в регионе серьёзное влияние оказала авария на АЭС Фукусима-1 в 2011 г., в результате чего Япония (крупнейший потребитель ядерной энергии до аварии) сократила производство ядерной энергии к 2018 г. на $83 \%$. В то же время высокими темпами вводятся новые мощности в Китае, где 
производство ядерной энергии за 2010-2018 гг. выросло в 4 раза, что сделало Китай третьей страной по объёму выработки ядерной энергии после США и Франции. Благодаря этому доля ядерной энергии в структуре потребления выросла до 2,1%.

Доля альтернативной энергетики в структуре энергопотребления составляет 3,8 \%. С 2010 г. производство энергии из альтернативных источников выросло более чем в 5,5 раз, а среднегодовой темп прироста составил 28 \% в год. Крупнейшими потребителями альтернативной энергетики являются Китай (64 \%), Индия (12\%) и Япония (11\%).

\section{Перспективы сотрудничества в энергетической сфере}

Основой сотрудничества России со странами АТР долгие годы являлся экспорт сырья, прежде всего углеводородов и металлов. Особенностью восточносибирских месторождений является то, что они смешанные по типу флюида, т.е. большинство из них содержат одновременно нефть, газ и конденсат. Вместе с тем, ряд крупных газовых месторождений отличается повышенным содержанием попутных ценных компонентов, таких как этан, пропан, бутаны и гелий. Выделение этих фракций может стать основой развития нефтегазохимических производств на востоке страны. Поэтому, если на востоке страны будут созданы мощности по переработке это сложного по составу газа, то Россия сможет решить сразу несколько стратегически важных задач - укрепление приграничной территории, увеличение численности населения за счёт повышения уровня и качества жизни, создания новых рабочих мест, а также дифференцировать доходы от экспорта за счёт реализации продукции с высокой добавленной стоимостью $[3,10]$.

Перспективные направления сотрудничества восточных территорий России со странами Азиатско-Тихоокеанского региона таковы:

- В случае роста спроса на нефть возможно увеличение мощности спецморпорта Козьмино за счёт организации поставок, в том числе по железной дороге из Западной Сибири.

- В 2019 г. акционеры проекта «Сахалин-1» (Ехxоn (30\%), «Роснефть» (20\%), Sodeco (30\%), ONGC (20\%)) приняли решение о строительстве завода по производству сжиженного природного газа в Де-Кастри. Планируемая мощность завода - 6,2 млн т в год, а стоимость строительства оценивается в 10 млрд долл.

- Рассматривается вопрос о строительстве «Восточного нефтехимического комплекса» компанией «Роснефть» при мерах государственной поддержки проекта. В рамках первого этапа планируется создать нефтеперерабатывающий завод мощностью 12 млн т, на втором этапе планируется строительство нефтехимического комплекса мощностью 3,4 млн т в год. Стоимость проекта оценивается в 1,5 трлн руб.

- Поэтапное увеличение поставок по магистральному газопроводу «Сила Сибири». В конце 2022 г. планируется подключение газопровода к Ковыктинскому место- 
Филимонова И. В., Немов В. Ю., Проворная И. В., Чеботарева А. В. Восточный вектор сотрудничества России со странами Азиатско-Тихоокеанского региона в энергетической сфере

рождению в Иркутской области. Выход газопровода на проектный уровень поставок 38 млрд куб. м в год планируется после запуска всех очередей Амурского ГПЗ в 2025 г.

- Компанией НОВАТЭК в 2017 г. подписано соглашение о сотрудничестве по созданию на юго-восточном побережье п-ова Камчатка морского перегрузочного СПГ-терминала. Строительство планируется начать в 2020 г. с запуском в эксплуатацию в 2022 г. и предположительным объёмом государственной финансовой поддержки в размере 28,8 млрд руб.

Российские нефтяные компании активно привлекают иностранные инвестиции не только в перспективные проекты, но и в уже действующие активы. Введение секторальных и финансовых санкций со стороны западных государств обусловили необходимость поиска новых источников и направлений заимствования. Так, одним из примеров активного сотрудничества со странами АТР стала компания «Роснефть», активно привлекающая партнёров из Китая и Индии в проекты на востоке страны - «Ванкорнефть», «Таас-Юрях нефтегазодобыча», «Верхнечонскнефтегаз» и «ВосточноСибирская нефтегазовая компания». Налажено сотрудничество с компаниями ONGC, Oil India, Bharat Petroresources, Beijing Gas, Sinopec и рядом других.

Партнёрские отношения со странами АТР в недропользовании также развивает Иркутская нефтяная компания (ИНК), осуществляющая совместную разработку месторождений Иркутской области и Красноярского края с Японской национальной корпорацией по нефти, газу и металлам (JOGMEC).

Также Роснефть имеет продолжительный опыт успешного сотрудничества с японскими партнёрами. В 1996 г. компания привлекла в проект Сахалин-1 пул иностранных компаний - SODECO (30\%), ExxonMobil (30\%) и ONGC Videsh Ltd. (20\%). Акционерами SODECO выступают правительство Японии, Japex, Itochu, Marubeni, Inpex.

Таким образом, богатейший ресурсный потенциал восточносибирских регионов обусловливает инвестиционный интерес стран АТР. Активное развитие приграничной инфраструктуры, прежде всего для трубопроводной и портовой, существенно повышает коммерческую эффективность поставок нефти и газа в Китай и другие страны Азиатско-Тихоокеанского региона. Однако решая задачу налаживания сотрудничества и развития партнёрских отношений, необходимо поддерживать эффективное освоение энергетического потенциала востока страны с точки зрения удовлетворения приоритетов социально-экономического развития региона, уровня и качества жизни населения, темпов роста экономики. Основой такого развития может стать формирование высокотехнологичных отраслей перерабатывающей промышленности на базе углеводородного сырья месторождений Восточной Сибири и Республики Саха (Якутия).

Создание новых обрабатывающих производств в нефтегазовом комплексе на востоке страны, переориентация технологии выпуска нефтехимической продукции 
с нефтяного на газовое сырьё, которым в достаточном объёме располагают регионы Восточной Сибири и Республики Саха (Якутия), а также продолжение развития транспортной инфраструктуры не только становится всё более важной задачей социально-экономического развития регионов и обеспечения энергетической безопасности России, но и служит реализации российских геополитических интересов.

\section{Список литературы}

1. Анализ транспортировки газа на экспорт из России / И. В. Филимонова, В. Ю. Немов, И. В. Проворная, С. И. Шумилова, Е. А. Земнухова // Транспорт: наука, техника, управление : науч. информ. сб. - 2019. - № 6. - С. 60-65.

2. Андреев, П. С. Преимущества и перспективы расширения экспорта сжиженного природного газа из России в страны АТР // Азиатско-Тихоокеанский регион: экономика, политика, право. - 2015. - №. 2. - С. 47-55.

3. Ершов, Ю. А. Роль Азиатско-Тихоокеанского экономического сотрудничества в экономической политике России // Российский внешнеэкономический вестник. - 2011. - Т. 2011, №. 9. - С. 11-20.

4. Коржубаев, А. Г. О стратегии взаимодействия России со странами АТР в нефтегазовой сфере // Проблемы Дальнего Востока. - 2010. - №. 2. - С. 64-77.

5. Коржубаев, А. Г. Перспективы и условия сотрудничества России и стран Тихоокеанского кольца и Восточной Евразии в энергетической сфере / А. Г. Коржубаев, И. В. Филимонова, Л. В. Эдер // Пространственная экономика. - 2012. № 2. - С. 23-29.

6. Телегина, Е. А. Сжиженный природный газ в Азиатско-Тихоокеанском регионе: обеспечение энергетической безопасности и возможности экспорта для России / Е. А. Телегина, В. А. Федорова // Нефть, газ и бизнес. - 2017. - №. 7. C. 41-50.

7. Филимонова, И. В. Экспорт нефти и нефтепродуктов из России на фоне мировых тенденций / И. В. Филимонова, И. В. Проворная, В. Ю. Немов // Транспорт: наука, техника, управление : науч. информ. сб. - 2019. - № 4. - С. 12-20.

8. Christoffersen, G. Russia's breakthrough into the Asia-Pacific: China's role // International Relations of the Asia-Pacific. - 2010. - Vol. 10, no. 1. - P. 61-91.

9. Ivanov, V. I. Russian Energy Strategy 2020: Balancing Europe with the AsiaPacific Region // Erina Report. - 2003. - Vol. 53. - P. 13-20.

10. Kuhrt, N. The Russian far east in Russia's Asia policy: Dual integration or double periphery? // Europe-Asia Studies. - 2012. - Vol. 64, no. 3. - pp. 471-493.

11. Makarov, I. A. Transformation of the economic model in Asia-Pacific Region: implications for Russia's Far East and Siberia // The political economy of Pacific Russia - Palgrave Macmillan, Cham, 2017. - P. 77-101. 


\section{References}

1. Filimonova I. V., Nemov V. Yu., Provornaya I. V., Shumilova S. I., Zemnukhova E. A. Analiz transportirovki gaza na eksport iz Rossii [Analysis of gas transportation for export from Russia]. Transport: nauka, tekhnika, upravlenie: nauchnyi informatsionnyi sbornik, 2019, no. 6, pp. 60-65.

2. Andreev P. S. Preimushchestva i perspektivy rasshireniya eksporta szhizhennogo prirodnogo gaza iz Rossii v strany ATR [Advantages and prospects for expanding the export of liquefied natural gas from Russia to the Asia-Pacific countries]. AziatskoTikhookeanskii region: Ekonomika. Politika. Pravo - Pacific RIM: Economics. Politics. Law, 2015, no. 2, pp. 47-55.

3. Ershov Yu. A. Rol' Aziatsko-Tikhookeanskogo ekonomicheskogo sotrudnichestva v ekonomicheskoi politike Rossii [The role of Asia-Pacific economic cooperation in the economic policy of Russia]. Rossiiskii vneshneekonomicheskii vestnik, 2011, no. 9, pp. 11-20.

4. Korzhubaev A. G. O strategii vzaimodeistviya Rossii so stranami ATR v neftegazovoi sfere [On the strategy of interaction between Russia and the Asia-Pacific countries in the oil and gas sector]. Problemy Dal'nego Vostoka, 2010, no. 2, pp. 64-77.

5. Korzhubaev A. G., Filimonova I. V., Eder L. V. Perspektivy i usloviya sotrudnichestva Rossii i stran Tikhookeanskogo kol'tsa i Vostochnoi Evrazii v energeticheskoi sfere [Prospects and conditions for cooperation between Russia and the countries of the Pacific Ring and East Eurasia in the energy sector]. Prostranstvennaya ekonomika, 2012, no. 2, pp. 23-29.

6. Telegina E. A., Fedorova V. A. Szhizhennyi prirodnyi gaz $\mathrm{v}$ aziatskotikhookeanskom regione: obespechenie energeticheskoi bezopasnosti i vozmozhnosti eksporta dlya Rossii [Liquefied natural gas in the Asia-Pacific region: ensuring energy security and export opportunities for Russia]. Neft', gaz i biznes, 2017, no. 7, pp. 41-50.

7. Filimonova I. V., Provornaya I. V., Nemov V. Yu. Eksport nefti i nefteproduktov iz Rossii na fone mirovykh tendentsii [Export of oil and oil products from Russia against the backdrop of global trends]. Transport: nauka, tekhnika, upravlenie: nauchnyi informatsionnyi sbornik, 2019, no. 4, pp. 12-20.

8. Christoffersen G. Russia's breakthrough into the Asia-Pacific: China's role. International Relations of the Asia-Pacific, 2010, vol. 10, iss. 1, pp. 61-91.

9. Ivanov V. I. Russian Energy Strategy 2020: Balancing Europe with the AsiaPacific Region. Energy Report, 2003, vol. 53, pp. 13-20.

10. Kuhrt N. The Russian far east in Russia's Asia policy: Dual integration or double periphery? Europe-Asia Studies, 2012, vol. 64, no. 3, pp. 471-493.

11. Makarov I. A. Transformation of the economic model in Asia-Pacific Region: implications for Russia's Far East and Siberia. In: The political economy of Pacific Russia. Palgrave Macmillan, Cham, 2017, pp. 77-101. 